\title{
REPRESENTATION OF INDONESIA IN WONDERFUL INDONESIA'S FEELING IS BELIEVING TOURISM ADVERTISEMENT: A CRITICAL DISCOURSE ANALYSIS
}

\author{
Sisilana Diah Mariastuti Poyk ${ }^{1}$, Yasmine Anabel Pandjaitan ${ }^{1}$ \\ ${ }^{1}$ Faculty of Humanities, Universitas Indonesia, poykmaria@gmail.com; yasmine_pandjaitan@yahoo.com
}

DOI: 10.17510/paradigma.v6i1.84.

\begin{abstract}
ABSTRAK
Artikel ini membahas representasi Indonesia dalam iklan pariwisata Wonderful Indonesia versi Feeling Is Believing (2012) melalui pendekatan analisis wacana kritis terhadap nation branding yang diwacanakan dalam iklan. Korpus penelitian ini adalah sebuah iklan pariwisata yang dikeluarkan oleh Kementrian Pariwisata Republik Indonesia pada tahun 2012. Tujuan dari penelitian ini adalah untuk melihat apakah wacana representasi Indonesia yang dibangun dalam rangka nation branding melalui iklan pariwisata Wonderful Indonesia: Feeling Is Believing sudah sesuai dengan tujuan dibuatnya iklan. Pendekatan analisis wacana kritis yang digunakan dalam penelitian ini ialah tiga dimensi communicative events analysis yang dirumuskan oleh Fairclough (1995). Hasil penelitian ini menunjukkan bahwa representasi Indonesia dalam nation brand Wonderful Indonesia pada wacana iklan belum sesuai dengan tujuan dibuatnya iklan karena elemen-elemen wacana iklan dan interaksi antarelemen tersebut belum mampu membangun nation brand yang dituju oleh pemerintah Indonesia.
\end{abstract}

\section{KATA KUNCl}

Representasi; nation branding; iklan pariwisata; analisis wacana kritis.

\section{Background}

Tourism in Indonesia has undergone a significant growth in the last couple of years due to the hugely increasing number of foreign tourists coming to the country. From 2010 to 2014, in-bound tourists visiting Indonesia rose from a little over 7 to 9.4 million travelers, which roughly suggests an increase of around 500,000 visitors for every following year (Indonesian Tourism Ministry, 2015). This achievement has given a cause for optimism for the Indonesian government to set and achieve an even higher target in developing the 
potentials of the tourism sector. In the 2015 ASEAN Summit, the Minister of Tourism, Arief Yahya, mentioned the ministry's main goals for four subsequent years (2015-2019). It aims to improve the Indonesian tourism sector's rank internationally and boost the number of both foreign and local tourists (Sompotan, 2015). One of the most important strategies to fulfill the goals is an effective tourism marketing, which in this case is done by the Indonesian government through the discourses of Wonderful Indonesia (for foreign tourists) and Pesona Indonesia (for domestic tourists).

The marketing strategy, branding a country to be marketed in order to achieve certain economic, political, or tourism goals, is commonly known as nation branding. Ying (2006) defines nation branding as "applying branding and marketing communications techniques to promote a nation's image."According to Yee (2009), although nation branding is a relatively new term, its concept has been around for quite long and is a further development of former concepts such as destination branding and place branding. Furthermore, Yee believes that nation branding has a higher level of complexity compared to the previous concepts because it is not only a branding process of a place as a tourism destination, but it is rather a process that involves a nation's society and values during the development of the nation's characteristics into a solid brand identity. Nation branding is believed by many scholars, including tourism scholars, to be one of the most important components of promoting a country as a tourism destination.

One successful country to brand itself is Malaysia. In 2012, the nation brand Malaysia Truly Asia attracted 25 million foreign tourists with a total of US\$ 19 million for the sector's GDP. (Panorama Magazine, n.d.). Malaysia may be a much smaller country in size compared to Indonesia; nonetheless, Malaysia successfully highlights the potential and presents the country's unique qualities to the world. Although a country's tourism potential and natural resources are important selling points in tourism, Malaysia has proven that an effective nation branding strategy is equally influential to a nation's tourism development. In this case, nation branding is not necessarily a solid guarantee of a country's tourism success. Some countries failed to formulate their nation brands that their tourism sectors were impacted significantly. Pomering (2013) writes that the use of humor in Australia's tourism advertisement So Where the Bloody Hell Are You? suffered the risk because humor is usually saturated with culture-specific signs that are difficult to translate to the audience of various cultural backgrounds. The following advertisement titled Come Walkabout released in 2008 to rectify the blunder did not help fix Australia's image because of the distorted and the inconsistent representation of the local tribe. Indigenous tribe of Australia was depicted to be culturally subordinate, which does not suit the 
reality at all. Thus, the audience, especially those with a prior knowledge of Australia's indigenous identity was given a space to be confused about "a clear, consistent, and agreeable image of Australia's identity as a holiday destination." The impact of this ineffective nation branding is shown by Pomering in the decreasing number of foreign tourists by $2.8 \%$ in 2008 when Come Walkabout was Australia's main tourism campaign.

Considering the success and failure of those two countries, a research on Indonesia's nation branding as a tourism destination is needed in order to enable Indonesia to follow the success and avoid the failure. Therefore, a research that explores how Indonesia presents itself as an internationally powerful tourism brand is worth doing. This paper observes tourism advertisement Wonderful Indonesia: Feeling Is Believing which was published by the Indonesian Ministry of Tourism in 2012 and broadcasted in and outside Indonesia. Besides the television, the ad can also be accessed on the ministry's official website. The research was done using a critical discourse analysis method. The proposed issue by the research is the correspondence between the representation discourses of Indonesia in the advertisement Wonderful Indonesia: Feeling Is Believing (2012) and the actual aim of the advertisement's production. Although the production process of the ad is not the main focus of this research, the process is also essential to be put into consideration while fulfilling the goals of the research. Thus, this research also used data related to the advertisement's production of discourse written in a research conducted by Stephanie (2014).

This research is inevitably limited. First, the scope of nation branding representation observed is limited to the advertisement which was chosen to be the corpus of the research. Other advertisements published by the ministry both on the website or other media are inseparable parts that compile the whole representation of Indonesia's tourism nation branding. Thus, the theory of representation is essential because the main interest of the research is representation. Second, the analytical framework used was Norman Fairclough's critical discourse analysis, which was originally established to critically observe news discourse. Nevertheless, the research included theories of other scholars related to advertisement discourse to supplement the theory in analyzing the data. In addition, the relation between pictures and narratives was also observed in the process.

\section{Literature Review}

Theories included in the research were the theory of representation by Hall, Barthes' semiotics, Organon model by Bühler, Fairclough's critical discourse analysis, and theories related to Cook's discourse 
of advertising. The theory of representation is crucial here because the fundamental aim of the research is to look at how Indonesia is represented in the tourism advertisement. Representation is one of the central practices in a process named by Du Gay, Hall et al. as the 'circuit of culture'. Representation is further defined by Hall as "an essential part of the process by which meaning is produced and exchanged between members of a culture" (Hall, 1997). Hall also defined it as the use of language to deliver or communicate something with meanings to other people. Similar to Hall, Gilles and Middleton (1999) agreed that representation is key practices in the production of meaning. They defined the term into three different meanings: (1) to stand in for, (2) to speak or act on behalf of, and (3) to re-present. Representation can generally be defined as a communicative process which illustrates an object with meanings in order to deliver the certain meaning of the object to other person or people. Representation is divided into two big systems: mental concept and language. The language here is not limited to verbal language because what Hall meant by language includes sounds, words, pictures, or objects that at the same time symbolize a meaning. The two systems function together simultaneously so that communication between a person and another can be facilitated through the language.

Barthes' semiotics theory is used in the research to find the connotative meanings in the logo in the corpus. In the semiotics world established by Roland Barthes (1967), the meaning of the object is the signified, while the object that carries the meaning is the signifier. The signified is not always in forms of real objects. The relation between signifier and signified is then divided by Barthes into two different levels of system, which are denotative and connotative. Denotative meaning is a simple, basic, descriptive signification where meaning resulted is agreed upon a common consensus. On the other hand, the connotative meaning is no longer a signification of a clear interpretation on the descriptive level, but it is rather closely related to "fragments of an ideology, a very close communication with culture knowledge [and] history..." (Barthes in Hall, 1997, p.39). Manifestation of ideology in connotative meaning is what Barthes called as myth. Two levels of meanings in Barthes semiotics theory are described in the table as follows:

\begin{tabular}{|l|l|l|l|}
\hline Language & 1. Signifier & 2. Signified & \\
\cline { 2 - 4 } & $\begin{array}{l}\text { 3. Sign } \\
\text { II. SIGNIFIER }\end{array}$ & \\
\cline { 2 - 3 } Myth & \multicolumn{1}{|c}{ III. SIGNIFIED } \\
\cline { 2 - 4 } & & II. SIGN \\
\hline
\end{tabular}

Table 1. Barthes Semiotics Model. 
Another key theory in this research is Bühler's Organon Model theory. The model is a theoretical framework which maps language representation and interpretation in communication. Bühler created a model which he called Organon Model where language has three semantic functions, which are expression, appeal, and representation. The relations between the three functions are mapped in the model below:

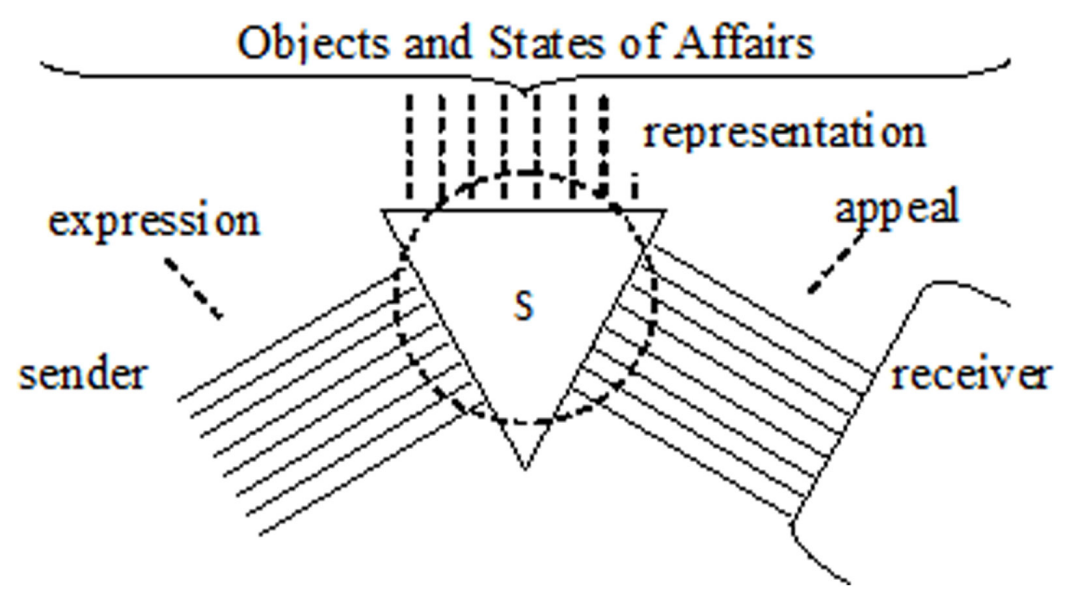

Figure 1. Bühler's Organon Model

Source: Bühler, K. (1990). Theory of language: The representational function of language (Vol. 25). John Benjamins Publishing.

The Organon Model above is used in the research to map the communicative process between the advertisement producer and respondents of the research. Besides the ability to map communicative process, the model can also show if the message is received as intended by the sender. The model also allows us to compare how the receiver interprets the message to the expectation of the sender. Moreover, if the expectation is not met, an observation can show if it is caused by false form expression, misrepresentation, or lack of appeal to the receiver.

The theory of advertisement discourse that is used in the research is the elements of advertisement discourse written by Guy Cook (1992). Advertisement discourse is inseparable from the media. El-Daly (2012) argues that "although advertising is all around, [people] do not often pause to think about its nature as a form of discourse, as a system of language use..."(p.1). Advertisement is actually an important discourse in contemporary society and its presence reflects how a society develops (Cook 1992). Advertisement is all kinds or forms of public announcement which are designed to promote sales of a certain commodity or service (Danesi 2002). In general, the main function of an advertisement is to persuade targeted people to buy the product being advertised. Besides, Cook (1992) explained that advertisement also has other 
functions as entertainment facility, information and awareness medium, or warning. Advertisement can be divided into three main categories: (1) consumer advertisement, (2) trade advertisement, and (3) public relations advertisement (El-Daly 2012). Advertisement as a discourse also has composing elements. Those elements are "participants, functions, substance, pictures, music, society, paralanguage, language, situation, other advertisements, and other discourses" (Cook 1992, p.3). The elements are searched in the corpus and observed to find the representation of Indonesia constructed within the discourse.

Critical discourse analysis theoretical framework is used to approach the data. According to Fairclough (1995), critical discourse analysis (CDA) is a discourse analysis which aims to systematically observe causality between discourse practice and wider socio-cultural structure. It also aims to seek how the relation is influenced and how the ideology is formed by power in society (p.132). In short, a result of a critical discourse analysis exposes an implicit message or meaning beneath a discourse. In this research, the implicit meaning is how Indonesia is represented in a tourism advertisement. In CDA, there are theorists who have focused and systematic frameworks on genre and socio-semantic representation within a discourse, but there are also those who combine various kinds of research methodologies (Blommaert and Bulcaen 2008). In this research, the method utilized is communicative event analysis, which is part of Norman Fairclough's critical discourse analysis framework. Communicative event analysis observes a discourse as a social practice which is composed of three dimensions: text, discourse practice, and social practice.

\section{Methods of Analysis}

The research uses both primary and secondary data. The primary data of the research is an official advertisement published by the Indonesian Ministry of Tourism in 2012 titled Wonderful Indonesia: Feeling Is Believing. The advertisement is five minutes long. It is accessible for free through the ministry's website and YouTube account when the research was conducted. Starring Johanna Suryanto and David John, the ad is directed by Condro Wibowo. Target audience of the advertisement are potential foreign tourists from developed countries including Hongkong, the United Kingdom, and other European countries (Stephanie 2014). The second primary data used is two interview transcripts with two foreign respondents who had never visited Indonesia until the research was finished. The two respondents were chosen because one has a prior knowledge of Indonesia, while the other did not. These two respondents should be able to give a rough description of how potential tourists coming to Indonesia usually fall into these two categories. 
They are not intended as a generalization for all tourists, but they serve as a window to understanding how the target market would receive and respond to the discourse built in the ad. Interviews were conducted with the two respondents through Facebook and Skype messengers. By getting into how a potential tourist evaluates Indonesia, we can get a valuable insight how the tourism ad is perceived. Besides the primary data, there are some secondary data included in the analysis. The secondary data are obtained from literary reviews. One secondary data is a research conducted by Stephanie (2014) on the production process of the advertisement. Other literary reviews were also done to look for other data related to historical contexts around the production period of the advertisement.

The research method is divided into three steps. The first step is making transcripts of speech and song of the advertisement and putting the advertisement into scene screenshots. The second step is selecting corpus and its transcript. Elements of some corpus were chosen to be observed in the analysis process. The selected parts of the corpus were chosen for their significance to representation of Indonesia within the advertisement. For example, occurrences of certain traditional arts or places, interaction between foreigners and local people, and contrast between traditionality and modernity, and other similar aspects in several scenes are crucial to be observed closely, for the purposes of their presence are closely related to the representation of Indonesia that the research aims to reveal. The chosen scenes were then put into a table which maps their pictures, narratives, written text, and song lyrics that appear in each the scene.

Last but not least, the chosen parts of the corpus were analyzed. The theoretical framework used to analyze is Analysis of Communicative Events (Fairclough 1995). It is divided into three levels:

\section{a. Text Analysis}

Text analysis observes the modes in the advertisement. The modes in the corpus of the research are song, speech, written text, picture, and paralanguage. The advertisement's elements were grouped into (1) function, situation, and substance, (2) other discourse and advertisements, and (3) music, pictures, paralanguage, and language. The elements were grouped based on their relevance with each other even though it is important to remember that an element in one group also has relevance with other elements which belong to different groups.

\section{b. Discourse Practice}

Discourse practice includes aspects related to the production, distribution, and consumption of the discourse. Fairclough conducted analysis in this level by interviewing people who are involved in the processes. In this research, the production process is obtained from literary review, a research done by Stephanie (2014). Meanwhile, the 
analysis of consumption process is done by interviewing two potential foreign tourists as the target audience of the advertisement.

c. Sociocultural Practice

Socio-cultural practice relates to the context and situation in society when the discourse was constructed. The analysis at this level is done through literary reviews and obtaining relevant data from the internet.

\section{Findings}

\section{a. Text Analysis}

Text analysis in the research was not only done to the main corpus but also to the logo and slogan of Wonderful Indonesia. The logo, which indicates the name of the product using special fonts (Cook, 1992), is the key sign which can trigger the intended discourse about Indonesia in the mind of the receivers. The aspects of the logo are mapped into Barthes' semiotic model.

\begin{tabular}{|c|c|c|c|}
\hline \multirow[t]{2}{*}{ Language } & 1. Signifier Logo & $\begin{array}{l}\text { 2. Signified } \\
\text { Wonderful } \\
\text { Indonesia }\end{array}$ & \\
\hline & \multicolumn{2}{|c|}{$\begin{array}{l}\text { 3. Sign } \\
\text { Wonderful Indonesia Logo } \\
\text { II. SIGNIFIER }\end{array}$} & $\begin{array}{l}\text { III. SIGNIFIED } \\
\text { Symbol of } \\
\text { the nation, } \\
\text { harmonious life, } \\
\text { togetherness, } \\
\text { desire to soar }\end{array}$ \\
\hline Myth & \multicolumn{3}{|c|}{$\begin{array}{c}\text { III. SIGN } \\
\text { Harmonious life and extraordinary uniqueness of Indonesia }\end{array}$} \\
\hline
\end{tabular}

Table 2. Wonderful Indonesia Logo in Barthes' Semiotic Model.

In addition to the mapping of the logo in terms of shape above, each colour of the logo is also mapped into the model. Based on the models, it can be seen that the grand narrative of Indonesia with all of its natural, cultural, social, and historical backgrounds is summarized in the logo Wonderful Indonesia. The government's representation of Indonesia can be summarized in a table as follows: 


\begin{tabular}{|c|c|c|c|}
\hline No. & \multicolumn{2}{|c|}{ Dimensions of Wonderful Indonesia Brand } & Characters Represented \\
\hline 1. & \multicolumn{2}{|l|}{ Brand name } & $\begin{array}{l}\text { Indonesia's physical and nonphysical } \\
\text { strengths }\end{array}$ \\
\hline \multirow[t]{8}{*}{2.} & \multirow{8}{*}{ Brand logo } & $\begin{array}{l}\text { Shape of a garuda } \\
\text { bird }\end{array}$ & Harmony of life and uniqueness \\
\hline & & Font & Ability to compete on an international scale \\
\hline & & & Colours \\
\hline & & Green & Creativity and friendliness \\
\hline & & Purple & Religious situation in Indonesia \\
\hline & & Orange & Openness \\
\hline & & Blue & Peace \\
\hline & & Magenta & Balance in life \\
\hline 3. & \multicolumn{2}{|c|}{ Feeling Is Believing Slogan } & Ability to prove its positive image \\
\hline
\end{tabular}

Table 3.Representation of Indonesia in Dimensions of Wonderful Indonesia Brand.

It can be seen that the Indonesian government's strategy to promote Indonesia through the brand is to present some characters as the selling points. The characters chosen are those that are considered Indonesia's strengths. This can be seen from at least three things in how Indonesia is represented through the brand. First, the selection of the brand itself uses the word wonderful which has the ability to show the character of Indonesia. Second, the word Indonesia is made bigger to make it stand out and 'stronger' than the other elements of the logo. This represents how the government wanted to show Indonesia's ability to stand out in international stage. In addition, the colours and shapes of the nation brand's logo were selected by the government for some reasons including how they can symbolize many 'selling' characters of the country. Third, the slogan of the advertisement is an indirect stimulus for the audience to prove Indonesia's positive image as a tourism destination by visiting Indonesia themselves. Later, these representations targeted by the government from the nation brand's dimensions were compared to the representation of Indonesia constructed in the advertisement video so that the similarity and disparity can be shown.

Based on the text analysis to the advertisement video, it can be concluded that Indonesian government generally tries to represent not only Indonesia's physical characters but also abstract characters to attract potential tourists. There are three significant things related to the balance of the two characters' representation. The first apparent thing is the use of Indonesian language as a medium to create imagination room of Indonesians' friendliness and openness. Such imagination room is defined by Crouch, Jackson, and Thompson (2005) as tourist imagination, a concept which depicts mobility of relation between tourism and 
the media. The actor's using Indonesian language along with a smile as a paralanguage results in an overall effect on the audience as Guy's "paralinguistic and linguistic effect" (1992) table shows below:

\begin{tabular}{|l|l|c|}
\hline \multicolumn{1}{|c|}{ Verbal Behaviour } & \multicolumn{1}{|c|}{ Paralinguistic Behavious } & Overall Effect \\
\hline $\begin{array}{l}\text { "Ini masukkan kesini." (?) } \\
\text { (Put this here) }\end{array}$ & Local weaver and Lisa smiling (+) & $(+)$ \\
\hline $\begin{array}{l}\text { "Apa kabar?" (?) } \\
\text { (How are you?) }\end{array}$ & David smiling(+) & $(+)$ \\
\hline $\begin{array}{l}\text { "Baik." (?) } \\
\text { (Fine.) }\end{array}$ & Local people smiling (+) & $(+)$ \\
\hline $\begin{array}{l}\text { "Halo." (+) } \\
\text { (Hello.) }\end{array}$ & Local people and Lisa smiling (+) & $(+)$ \\
\hline
\end{tabular}

Table 4. Paralinguistic and Linguistic Effects of Bahasa Indonesia in the Advertisement.

The smile as a paralanguage is used as a clue for the targeted foreign audience to interpret the verbal interactions as a positive communication process. Some paralanguages have a universal meaning and therefore huge impact on how someone interprets a sign. One of such paralanguages is people's perception on friendliness and unfriendliness as proven by Ellis and Beattie (1986) in Cook (1992). They stated that "When subjects were asked...to recall whether they had been treated in a friendly or unfriendly manner, their replies correlated only with the paralinguistic behavior (p.67)". The use of smile as a paralanguage in interactions between tourists and local people here is a strategy to represent Indonesian people as friendly and open. This is one of the aspects of the nation brand that the government wanted to show: Indonesian people and their characters.

Second, the representation of both traditional and urban Indonesia is is shown in alternating scenes to show balance and harmony between the culture and the modernity of the country. From several scenes which represent the traditional facet of Indonesia, the advertisement discourse seems to place local people and foreign tourist at the same level. Indonesians are not again portrayed as a pleasure periphery (surrounding the tourists as the focus of a pleasure activity) which is often shown in many tourism advertisements. 


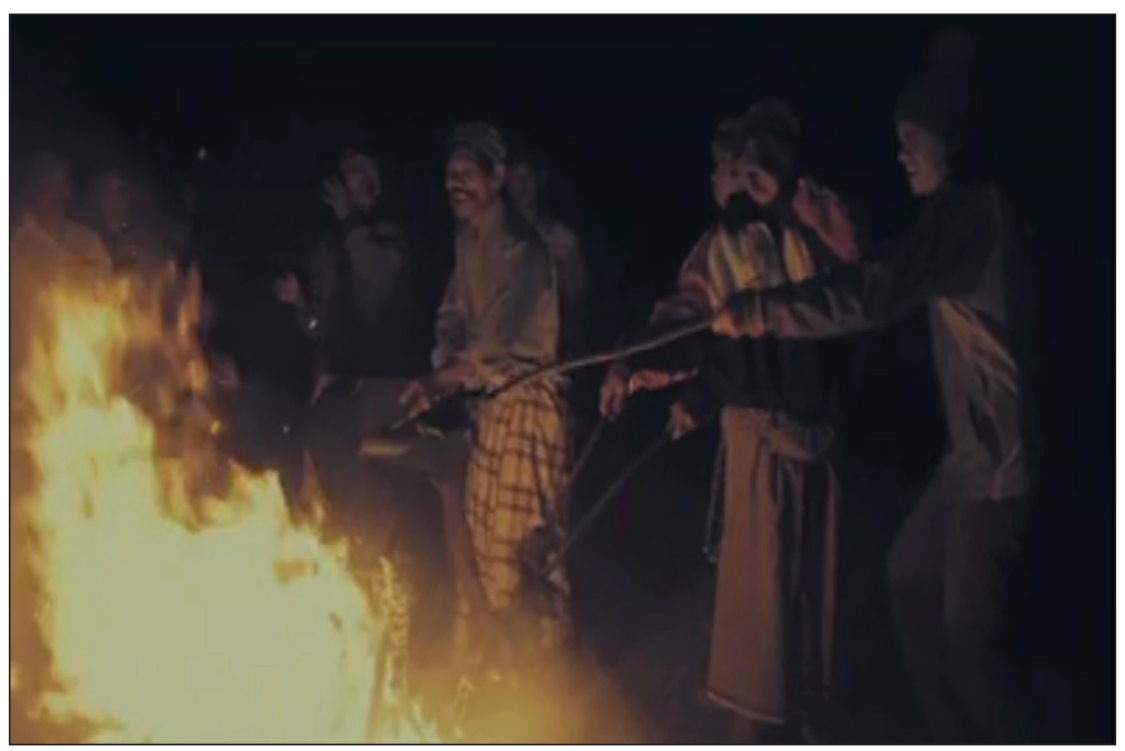

Figure 2. Wae Rebo Scene and The Narrative.

Nevertheless, there is a little inconsistency between the effort to equalize the positions and the over exotic depiction of Indonesia. One of the scenes that shows this most visible discrepancy is the Wae Rebo village scene which shows the male cast with local people enjoying their time by the fireplace. The narrative to accompany the scene mentions 'wild life'. The narrative adds up to a meaning that puts Indonesian traditional life depicted as a form of wilderness which is uncommon for the target audience' modern life, thus altering the Indonesian locals' previous equal position to be once again inferior to the foreign tourists.

In contrast, the scene which depicts Indonesian modernity comes with the narrative "life that charge you beyond limit" [sic]. The narrative uses pronoun 'you' to address the audience directly. The narrative represents how Indonesia can also provide an experience that can take the tourists past their expectation limit. The limitation here is related to how Indonesia's image as a tourist destination is usually of the traditional culture or nature. After showing the audience how the exotic traditional cultural image of Indonesia is true, the discourse tries to balance the representation by bringing up this scene. It offers luxurious shopping facility and the female cast shopping at the mall to imply that Indonesia has the ability to serve such luxury to the tourists, too. The consequent implication of this imagery, that such luxury is part of Indonesian life, shows how Indonesia has succeeded in advancing its economy.

Third, while the representation of Indonesia's abstract qualities was very carefully detailed, the representation of its physical characters still appears to be dominant in the discourse. Some proportions of physical characters representation; however, were actually connected to the abstract characters. The natural outdoor destinations were not shown as places to go, but they were constructed as an important part 
of David's and Lisa's journey in 'feeling' Indonesia. Nevertheless, there were still many representations of physical characters which focus solely on the beauty of nature. Physical characters related to Indonesia's historical values were still overshadowed by the discourse of its natural beauty. As shown in the last scene that closes the advertisement, the character represented was still the beauty of nature which was depicted by Lisa and David staring at a mountain together. This closing scene shows how the government still puts forward the Indonesian physical character as the main selling point and thus the tendency to represent Indonesia physically even though the message of the nation brand's message has a balanced representation of both its physical and abstract qualities.

\section{b. Discourse Practice Analysis}

Discourse practice analysis observes the production and consumption processes of a discourse. The process that is the main focus of this research is the consumption process which serves as the primary data and includes the receivers' interpretations of the message. Interpretations of target audience observed are the ones related to the elements which are found to be significant based on the text analysis. Out of the three dimensions embedded in the nation brand, the interpretation towards the logo Wonderful Indonesia expected by the government is not fulfilled. The logo does have appeals for the target audience because they like and have interest in the logo. However the appeals do not lead them to the message sent through the logo by the government. The appeal to them is mere combination of colours that does not carry specific meanings. It can be said that messages that are communicated by the government through the logo are not delivered because the audience are not familiar with the shape of Garuda bird, and colors are interpreted differently in each culture. Thus, delivering messages through colors is not effective in this case. Here is the respondents' interpretation of logo mapped in Bühler's Organon Model:

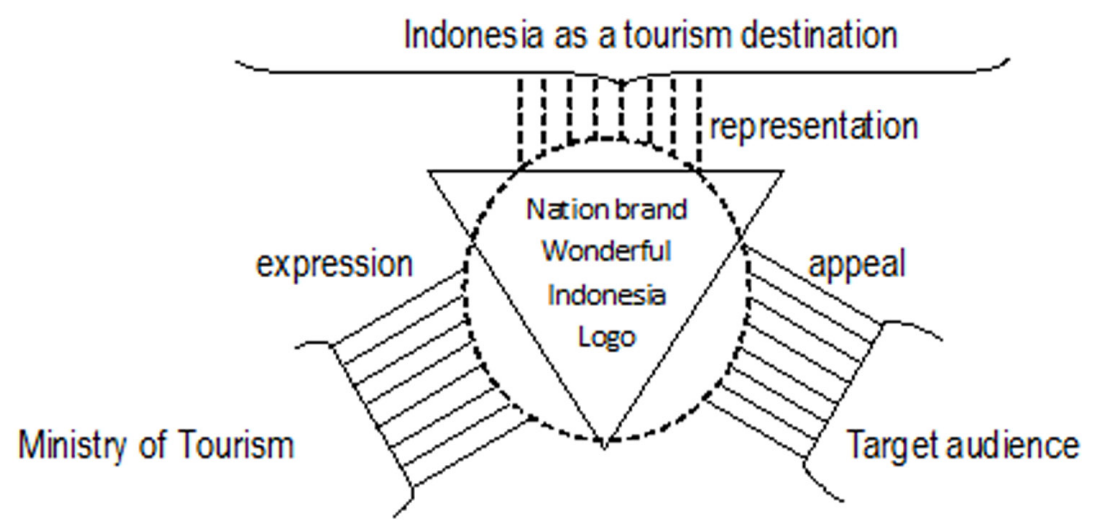

Figure 3. Nation Brand Wonderful Indonesia's Logo in Bühler's Organon Model. 
There are several significant interpretations mapped into the model related to the representation of physical and abstract qualities of Indonesia. First, the representation of friendliness of Indonesians is one of the several representations interpreted as expected by the target audience. The interpretation process of how Indonesians are represented as friendly and open can be seen in the model below.

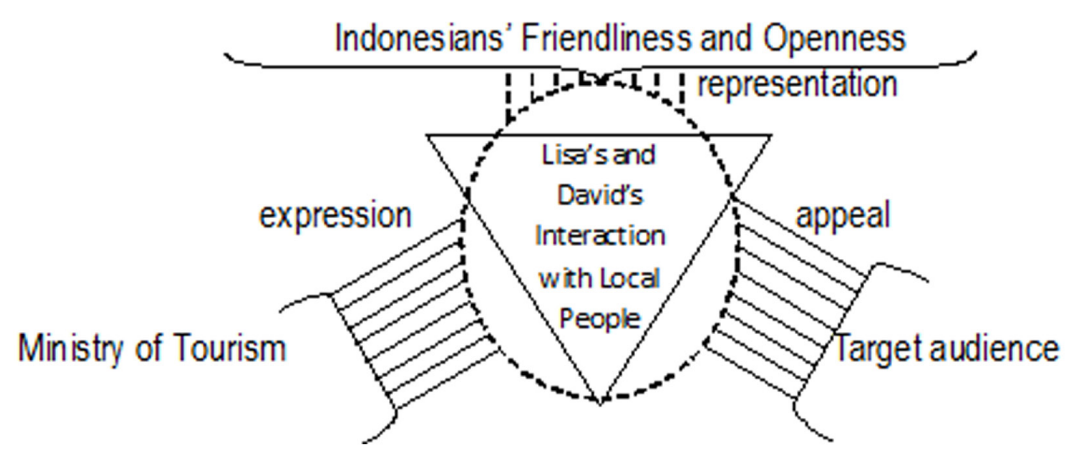

Figure 4. Friendliness and Openness of Indonesians in Bühler's Organon Model.

Both respondents got the same impression that Indonesians are friendly after watching the advertisement. The first respondent, who did not have prior knowledge of Indonesia, said that "IIndonesian people] seemed friendly". Meanwhile, the second respondent, who had more background knowledge of Indonesia said that "[Indonesian] people is the reason why I'm attracted to Indonesia. Specifically all the people that I know are so friendly and outgoing and want to meet people and learn". The second respondent furthermore expressed that his expectation on Indonesian people is met in the advertisement. This shows that the message on abstract character of Indonesians instilled in the discourse by the ministry can be delivered well to the audience because it has appeal for the audience. The scenes which represent Indonesians can deliver the message because the combination of all picture, narrative, and paralanguage elements refer to a positive meaning. Thus, the character of friendliness and openness can give appeal to the target audience.

Second, representation of harmonious traditionality and modernity in Indonesia is not interpreted as expected. Here is the interpretation towards traditionality and modernity in Indonesia mapped in a Bühler's Organon Model: 


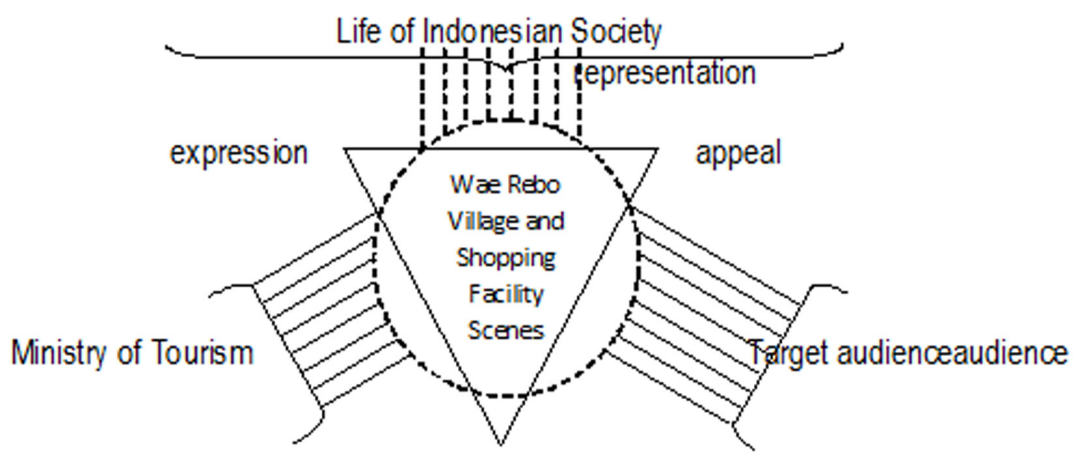

Figure 5. Indonesian Traditionality and Modernity in Bühler's Organon Model.

The traditional life of Indonesia is well delivered by the discourse because it has appeal for the target audience. However, the modern Indonesia is not captured by the respondents that the message on development of the country is not delivered successfully. The second respondent expressed that "...if there's something that's missing, it's not that much in the city. It's nice that they show the nature and outdoor because frankly l'm not so interested in visiting Jakarta because I live in Chicago. I already live in a big city". The life of Wae Rebo Village represented as a 'wild life' indeed has the appeal for the target audience, who live in modernity. On the other hand, the respondent also said that the shopping facility does not fulfill his expectation of seeing the city's commercial aspects which are more of the street shopping and foods, hotels, and transportations. There are scenes which have those aspects; nevertheless, the fact that the respondent complained about his unfulfilled expectations shows that the scenes with those aspects do not have appeals for him. For instance, the commercial aspect of developed modernity in Indonesia is represented by a scene where Lisa was shopping in a luxurious mall. The scene was not delivered to both respondents because the expression of the message uses signs that have no appeal at all for male respondents. The activity done in the scene, window shopping for luxurious bags, is not strong enough and too irrelevant to be tourist imagination for both respondents.

Both respondents have the tendency to interpret the advertisement as a discourse which focuses on the physical characters of Indonesia especially nature. The first respondent, who has no prior knowledge of Indonesia at all, described the country with the word 'beautiful' and said that it is the "scenery which makes [Indonesia] beautiful". On the other hand, the second respondent used the words 'warm', 'green', and 'friendly' before watching the advertisement. After watching the advertisement, he changed those words and 
described Indonesia with 'the nature', 'the people', and 'the ancient temples'. He said that the advertisement reminded him of those words. He added that those three things are the strongest characters shown by the advertisement. Although the second respondent took the messages of abstract qualities of Indonesia (friendliness and historical value), nature comes first and shows how the advertisement still has the tendency to make nature stand out and dominant. Based on how the advertisement made the respondents describe Indonesia, nature is still a dominant quality in the advertisement discourse.

Interpretation towards the representation of Indonesian physical nature in the target audience is accompanied by the representation of adventurous nuance provided by the choices of natural destinations. Such an interpretation is shown clearly by how the second respondent stated, "There's a lot of emphasis on adventure and nature." He then said that he "think it focuses on the adventure. Somebody might have expected that." His own expectation was not of nature because he had good knowledge about Indonesia. He even had a list of destinations he would like to visit if he comes to Indonesia. Compared to him, the second respondent had major focus on the physical characters of Indonesian nature. The destination which has the most appeal for him is the waterfall and rafting activity. This might be caused by the combination of the pictures of destination appearing in combination with other elements so that it can give a lot of appeals for the audience.

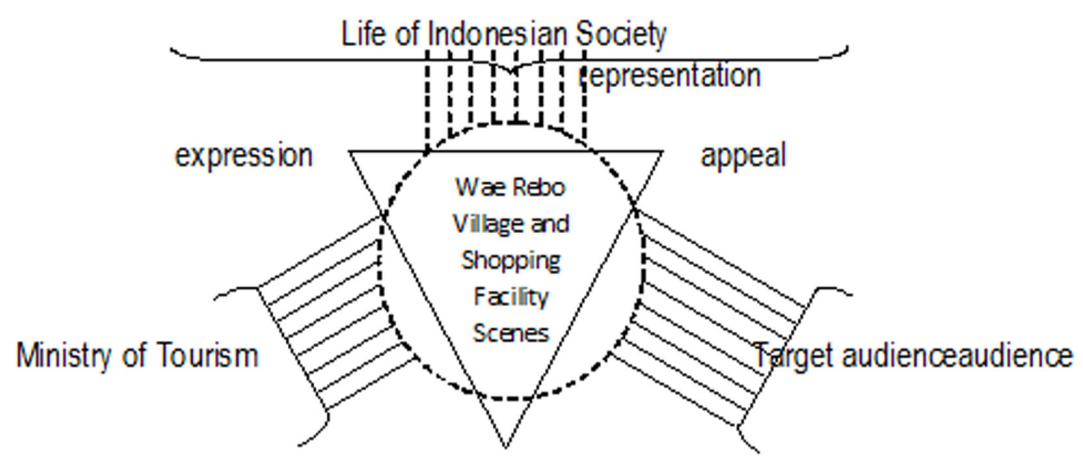

Figure 6. Representation of Indonesian Nature in Bühler's Organon Model.

Different with the first respondent, the second respondent has adequate knowledge of ecological issues in Borneo and how certain parties in Indonesia are abusing the nature and its resources. Thus, he thought the scenes which show the nature in the advertisement are far too dominant remembering the presence of such issues. In addition, the balanced harmonious life with the nature was not also captured by 
the respondents. The proportion of representation has too wide of a gap that the particular message was not interpreted by the respondents. The elements of the advertisement add too much appeal to the natural qualities of Indonesia instead of the balanced physical and abstract qualities.

One of the things worthy of observation is the scene which depicts religious situation in Bali, which although famous, was not able to have appeal for the audience to interpret religious situation in Indonesia. Here is the interpretation process of both respondents towards religious situation in Indonesia through the scene:

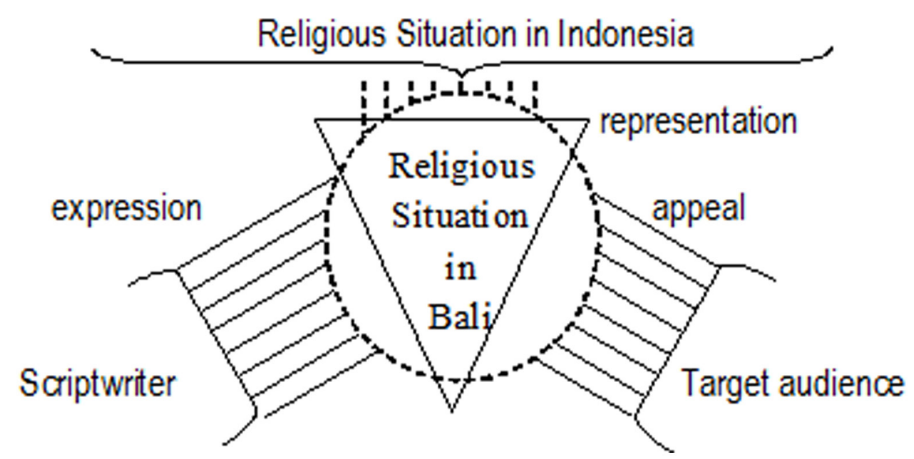

Figure 7. Interpretation of Religious Situation in Bali in Bühler's Organon Model.

In spite of that, the insertion of tourist imagination in the advertisement discourse needs to be credited to be successful. It can be seen from both respondents' preferences for activities and destinations after watching the discourse. The first respondent answered, "I want to see all of what Indonesia has to offer", while the second respondent said, "I can imagine myself doing most of them". However, activities related to the religious situation did not occur as a message captured by both respondents.

Another point of analysis is that the nation branding Wonderful Indonesia strategy instilled in the advertisement Feeling Is Believing discourse has two weaknesses. First, the choice of substance which is a short film cannot give enough information about important things related to Indonesia as a tourism destination. There is some missing information including the form of the country itself, the location of the places depicted, and the diverse life in Indonesia. Both respondents paid attention to the friendliness of the people and the wonderful nature of Indonesia but failed to receive the whole message of the brand due to the lack of information on the physical forms of Indonesian islands and its life characteristics. Multiculturalism in Indonesia was shown from the traditional house, dances, and arts from various regions. However, how those 
wonderful diverse aspects are present in a complete life of the people in Indonesia was not at all depicted. Therefore, the message of the nation brand fails to provide the respondents with a whole image of what Indonesia is. The aesthetic value of the advertisement has actually distorted the nation's reality, which is a crucial part of a nation brand.

Second, the representation of Indonesia through the advertisement has not successfully delivered the intended messages without ignoring the actual image of Indonesia in the eyes of international world. The nation branding strategy of Wonderful Indonesia seen from the advertisement points out the beauty of Indonesia's nature, culture, and people which can amaze the audience. In reality, not all target audience interpret the message in the same way. For instance, the second respondent admits the value of Indonesia's natural beauty but expects more than that by arguing that every country has its own natural beauty. The representation of Indonesia's nature shown by the brand through the discourse then can be seen as too general so that what appeals to the audience is not something unique and cannot contribute significantly to the nation brand. In addition, Indonesia has both positive and negative images in the world stage. The unique multiculturalism of Indonesia is something not many countries have and a great potential to be promoted as a huge part of the nation brand. The word wonderful is undeniably correct to describe Indonesia, but there needs to be a certain character or quality of Indonesia which is wonderful and authentic at the same time to be promoted.

\section{Sociocultural Practice Analysis}

The results of text and discourse practice analysis are then mapped into a table so that we can observe the probably related sociocultural practices to the two analyses. The table below shows more clearly how the expected interpretations are similar or different to the respondents' interpretations and what sociocultural difference that probably caused the difference and similarity.

\begin{tabular}{|l|l|l|}
\hline \multicolumn{1}{|c|}{ Text Analysis } & \multicolumn{1}{|c|}{ Discourse Practice Analysis } & \multicolumn{1}{c|}{ Sociocultural Practice Analysis } \\
\hline Indonesia's natural qualities & $\begin{array}{l}\text { Interpreted as expected by one of } \\
\text { two target audience }\end{array}$ & $\begin{array}{l}\text { Interest on natural tourism of the } \\
\text { target audience } \\
\text { Prior knowledge on ecological } \\
\text { issues in Indonesia }\end{array}$ \\
\hline $\begin{array}{l}\text { Indonesia's economic and } \\
\text { infrastructure development }\end{array}$ & Not interpreted by all target audience & $\begin{array}{l}\text { Target audience's socioeconomic } \\
\text { background of developed countries }\end{array}$ \\
\hline Religious situations in Indonesia & Not interpreted by all target audience & $\begin{array}{l}\text { Difference perspectives of target } \\
\text { audience in looking at religions }\end{array}$ \\
\hline
\end{tabular}




\begin{tabular}{|l|l|l|}
\hline \multicolumn{1}{|c|}{ Text Analysis } & \multicolumn{1}{|c|}{ Discourse Practice Analysis } & \multicolumn{1}{c|}{ Sociocultural Practice Analysis } \\
\hline $\begin{array}{l}\text { Authenticity of Indonesian traditional } \\
\text { culture }\end{array}$ & Not interpreted by all target audience & $\begin{array}{l}\text { Interest of target audience was not } \\
\text { to cultural tourism }\end{array}$ \\
\hline $\begin{array}{l}\text { Indonesian people's friendliness and } \\
\text { openness }\end{array}$ & Interpreted by all target audience & $\begin{array}{l}\text { Paralanguage with a universal } \\
\text { meaning }\end{array}$ \\
\hline
\end{tabular}

Table 5. Comparison of Analysis Points on Three Levels.

Representation of Indonesia's natural physical characters is very dominant in the discourse and was interpreted as expected by the target audience although one of the respondents had slightly different interpretation due to his prior knowledge of ecological issues in Indonesia, which decreases his positive impressions on Indonesian natural tourism attractions. The economic developments represented by the occurrence of luxurious shopping facility and Jakarta's infrastructure was not interpreted as expected because both respondents are from developed countries so that such an image is already part of their daily life. The importance of religiosity in Indonesia was also not interpreted by both respondents because their different perspectives in looking at religions. They took the imagery of religiosity in Bali as part of Indonesian traditional culture instead of the representation of religiosity's importance in Indonesia. The uniqueness of Indonesian traditional cultures was not interpreted as expected because its representation was dominated by the representation of Indonesian natural tourism destinations. Meanwhile, the representation of Indonesians' friendliness and openness was interpreted and delivered successfully because the scenes in which the representations occur use a paralanguage which has a positive universal meaning.

\section{Conclusion}

Based on the findings, it can be concluded that the advertisement discourse successfully managed to deliver the message of Indonesians' friendliness and openness through the representation. On the other hand, most of the other messages were not due to the lack of appeal of the messages for the target audience, ineffective form of expression, and different perspective towards the signifiers in the discourse. The aim of the discourse production is partially achieved. The government's aim to show the strength of green tourism in Indonesia through the nation brand represented in the advertisement discourse is achieved but merely through the representations of physical wonders. The aim to represent creative tourism through Indonesia's abstract characters is not yet achieved. 
In addition, there are also two interesting points found. The first is the representation of nation brand in the advertisement discourse has not been able to make the audience imagine the strengths shown in the advertisement as pieces that hold together Indonesia as a nation. Second, the discourse which does not provide many details about the commercial aspects in Indonesia has not been able to persuade the audience to access the official website which provides the information. The absence of those direct details in the advertisement decreases the persuasive message's appeal of the nation brand. The quality 'wonderful' represented in the advertisement is delivered to the target audience, but the aim of attracting the audience is not achieved.

The initial aim of the discourse production is not fulfilled because, in the advertisement, it can be seen that Indonesian government is still pressured by the tendency to focus the representations on exoticism. It is contradictory to the effort to alter Indonesia's position as a mere passive object of the tourist imagination in the advertisement shown by some scenes. This confirms some previous researches on inconsistent representations of a nation brand. The effort to show Indonesia's modernity, development, and creativity are out dominated by the representation of the country as a mere exotic destination to satisfy the target audience. Instead of depicting life in Wae Rebo as wildlife, for instance, the government can add the representation of the local people learning English to develop themselves as a foreigners-friendly destination, which significantly shows and promotes creative tourism.

As expected in the beginning of the research, this research supplements and continues the conversation on nation branding issues previously conducted. If in the previous researches, the issues observed are those of countries which are either total failures or successes, the nation brand Wonderful Indonesia cannot be categorized as such. It can be concluded that the nation brand stands in between those two categories. The nation brand does not completely fail in delivering its message as it manages to reach some of the goals set. Nonetheless, most of the nation brand's qualities represented in the advertisement have not been able to be interpreted as expected by the messages' sender. Therefore, the representation of the nation brand in this advertisement cannot also be considered as a complete success. Moreover, an evaluation towards the brand and its representation is crucial should be conducted before any revision towards the brand is produced in the future. 


\section{References}

Barthes, R. 1967. Elements of Semiology. Translated by Jonathan Cape Ltd. New York: Hill and Wang.

Blommaert, Jan, and Chris Bulcaen. 2000. Critical Discourse Analysis. Annual Review of Anthropology 29: $447-466$.

Bühler, K. 1990. Theory of language: The representational function of language. Foundation of Semiotic 25. Amsterdam/Philadelphia: John Benjamins.

Cook, G. 1992. The discourse of advertising, 1-59. London: Routledge.

Crouch, D., Jackson, R., \& Thompson, F., eds. 2005. The media and the tourist imagination: Converging cultures. London: Routledge.

Danesi, M. 2002. Understanding media semiotics. London: Arnold.

Du Gay, Paul, ed. 1997. Production of culture/cultures of production. London: Sage in association with Open University.

El-daly, H. M. 2012. Toward an understanding of the discourse of advertising: Review of research, with special reference to Egyptian media. Global Journal of Human-Social Science Research, 12(4).

Fairclough, N. 1995. Media Discourse. London: Arnold.

Fan, Y. 2006. Branding the nation: What is being branded? Journal of vacation marketing, 12(1), 5-14.

Gilles, J. \& Middleton, T. 1999. Studying Culture:APractical Introduction, 56-57. Oxford:Blackwell Pubslishers.

Hall, Stuart. 1997. Representation: Cultural representations and signifying practices. Vol. 2. Sage.

Kementrian Pariwisata. 2015. Perkembangan Bulanan Wisatawan Mancanegara, 2010-2014. Pemerintah Republik Indonesia.

Kementrian Pariwisata. 2014. Logo <i>Wonderful Indonesia dan Pesona Indonesia</i>. http://www.parekraf. go.id/asp/detil.asp?c=6\&id=2026.

Pomering, A. 2013. Indigenous identity in the nation brand: tension and inconsistency in a nation's tourism advertising campaigns. Corporate Reputation Review, 16 (1), 66-79.

Sompotan, J. 2015. Arief Yahya Ingin Ubah Ranking Pariwisata Indonesia. Okezone. http://lifestyle.okezone. com/read/2015/02/07/406/1102684/arief-yahya-ingin-ubah-ranking-pariwisata-indonesia.

Stephanie, R. F. 2014. Representasi Mooi Indie (Hindia Molek) dalam Iklan Pariwisata Indonesia (Analisis Semiotika Iklan Pariwisata Televisi (TVC) Versi Feeling Is Believing). Jurnal IImu Komunikasi. http://ejournal.uajy.ac.id/6577/1/JURNAL.pdf. 
Panorama Magazine. n.d. Visit Malaysia Year 2014. http://www.panorama-magz.com/newsflash/visitmalaysia-year-2014.

Yee, F. W. 2009. Nation branding: A case study of Singapore. UNLV Theses/Dissertations/Professional Papers/Capstones. Paper 712. 